\title{
Berpikir Positif Terhadap Komunitas Motor
}

\author{
Rima Apriza \\ Fakultas Psikologi \\ Universitas Ahmad Dahlan Yogyakarta \\ rimaapriza5@gmail.com
}

\begin{abstract}
Abstrak
Komunitas motor merupakan wadah bagi pemilik motor yang ingin lebih mengeksplore hobi mereka. Anggota dari komunitas motor biasanya terdiri dari pemiliki motor dengan brand yang sama atau bisa juga dengan berbagai brand. Subjek penulisan ini adalah komunitas motor Jogja CBR Riders Independent (JCRI).Tujuan penulisan ini diharapkan dapat merubah pemikiran negatif dari masyarakat terhadap komunitas motor, karena komunitas motor ini melakukan kegiatan yang positif untuk membuktikan terhadap masyarakat melalui kegiatan bakti sosial. Komunitas motor ini juga memberikan bantuan untuk korban banjir dengan cara memberikan kebutuhan sandang dan pangan.. Data penelitian diperoleh dari observasi dan wawancara serta teori dari berbagai sumber. Hasil penelitian menunjukkan bahwa Jogja CBR Riders Independent (JCRI) adalah sebuah komunitas motor yang memiliki keinginan merubah pemikiran negatif masyarakaat menjadi pemikiran yang positif terhadap komunitas motor.
\end{abstract}

Kata kunci : berpikir positif, kopdar, komunitas, komunitas motor, motor

\section{PENDAHULUAN}

Komunitas adalah jaringan dari beberapa individu yang berbentuk kekeluargaan, kemudian saling mengikat dalam meningkatkan sosialisasi sesama jaringan, saling mendukung dan mensuport satu sama lain, memberikan informasi, adanya rasa memiliki persatuan yang erat dan menjadi identitas social (Wellman dan Delanty, 2003). Sementara itu Hermawan (2008) menjelaskan arti dari komunitas adalah sekelompok atau kumpulan individu yang memiliki kepedulian satu sama lain lebih dari jumlah seharusnya, dimana sebuah komunitas terjadi relasi pribadi yang erat antara para anggota komunitas tersebut terhadap suatu ketertarikan hal yang sama. Komunitas termasuk dari kelompok sosial, kelompok sosial merupakan himpunan atau kesatuan-kesatuan manusia yang hidup bersama, oleh karena itu adanya hubungan dan timbal balik diantara mereka, namun himpunan manusia dapat dikatakan sebagai kelompok sosial jika didalamnya terdapat 
kesadaran kelompok, hubungan timbal balik antara anggota dan kepentingan bersama (Soekanto, 2006).

Komunitas Jogja CBR Riders Independent (JCRI) berdiri pada tanggal 31 Juli 2016, yang di ketuai oleh Ferdy Yuniarto. Komunitas ini terdiri dari 41 anggota. Komunitas Jogja CBR Riders Independent (JCRI) adalah suatu kelompok yang mencintai motor CBR dan memiliki hobby yang sama yaitu pada sepeda motor. Komunitas motor JCRI ini mempunyai tujuan agar masyarakat dapat berpandangan positif terhadap komunitas motor. Perbedaan antar komunitas dan geng motor ini adalah komunitas motor JCRI selalu berusaha melengkapi kendaraan dengan atribut komunitas dan kelengkapan kendaraan lainnya yang sangat mendukung dalam pelaksanaan touring. Banyak kegiatan positif yang mereka lakukan saat berada di jalan raya mereka sangat mematuhi tata tertib lalu lintas, mereka melakukan kegiatan bakti sosial untuk membantu korban yang terkena musibah. Karena hal tersebut sesuai dengan tujuan komunitas yang ingin membuktikan terhadap masyarakaat bahwa tidak semua pecinta motor melakukan kegiatan negative namun komunitas motor JCRI adalah komunitas motor yang memiliki aturan dan nilai positif yang harus diikuti oleh semua anggotanya.

\section{PEMBAHASAN}

Menurut Sakina (2008) Berpikir positif ini adalah pikiran yang dapat membangun dan memperkuat kepribadian diri dan karakter. Berpikir positif ini secara logis untuk melihat sesuatu dari segi positifnya saja baik terhadap dirinya sendiri, orang lain, maupun keadaan lingkungannya. Sehingga, mereka tidak mudah putus asa dan dapat mencari jalan keluarnya. Berpikir positif adalah satu kesatuan yang mengisi suatu pemikiran dengan berbagai hal yang positif. Memasukan muatan yang ada dipikiran merupakan tindakan yang positif namun, tindakan positif tersebut tidak di wujudkan dalam bentuk nyata, pada pengawasan pikiran inilah mencakup usaha untuk mengtahui muatan yang terdapat dalam ruang lingkup pikiran, sehingga dapat dilakukan dengan tindakan berupa pendapat negatif dan menggantinya dengan positif (Ubaedy, 2007). Sementara itu menurut Elfiky (2008) proses berpikir berkaitan erat dengan konsentrasi perasaan sikap, dan perilaku. 
Hasil penelitian Tentama $(2010 ; 2012$; 2014) menemukan bahwa berpikir positif mampu meningkatkan penerimaan diri. Hurlock (2006) menyatakan bahwa penerimaan diri merupakan kemampuan menerima segala hal yang ada pada diri sendiri baik kekurangan maupun kelebihan yang dimiliki, sehingga apabila terjadi peristiwa yang kurang menyenangkan individu tersebut akan mampu berpikir logis tentang baik buruknya masalah yang terjadi tanpa menimbulkan perasaan, permusuhan, perasaan rendah diri, malu dan rasa tidak aman.

Berpikir positif merupakan suatu cara berpikir yang lebih menekankan pada hal-hal yang positif, baik terhadap diri sendiri, orang lain maupun situasi yang dihadapi. Setiap pemikir positif akan melihat setiap kesulitan dengan cara yang gamblang dan polos serta tidak mudah terpengaruh sehingga menjadi putus asa oleh berbagai tantangan ataupun hambatan yang dihadapi. Individu yang berpikir positif selalu didasarkan fakta bahwa setiap masalah pasti ada pemecahan dan suatu pemecahan yang tepat selalu melalui proses intelektual yang sehat maka, mereka akan membuktikan terhadap masyarakaat bahwa komunitas motor tersebut tidak seperti yang masyarakaat pikirkan (Peale, 1996).

Pada awalnya anggota komunitas motor JCRI yang masuk adalah anak-anak yang terjebak dalam kenakalan remaja atau pergaulan yang salah. Mereka menjadi anak-anak geng motor pada awalnya karena pergaulan yang salah dari teman-teman sebayanya. Namun, saat anak tersebut masuk ke dalam komunitas JCRI, mereka mendapatkan dukungan dan saran positif dari para senior sehingga mereka menjadi pribadi yang lebih baik. Komunitas JCRI seringkali mengajak anggotanya melakukan kegiatan positif di masyarakat yang sehingga mereka bisa memiliki rasa bangga karena bermanfaat untuk orang lain.

Untuk mewujudkan citra masyarakaat Komunitas motor JCRI, maka komunitas motor ini membuat program untuk mengembalikan pandangan positif masyarakaat.

1. KOPDAR (Kopi Darat), yaitu mengelililingi kota Jogja, Kegiatan ini biasanya dilakukan satu kali pada hari Sabtu Malam.

2. Kegiatan Sosial Kegiatan sosial yang diadakan oleh komunitas JCRI antara lain Bakti sosial untuk memberikan kepada orang yang membutuhkan, seperti fakir miskin, korban yang terkena bencana.Korban yang terkena bencana ini adalah korban banjir 
yang berada di daerah Bantul, sedangkan memberikan fakir miskin ini mereka memberikan makanan kepada orang yang membutuhkan.

3. Touring. Kegiatan ini diikuti oleh semua anggota komunitas JCRI.

Komunitas motor JCRI selalu optimis ketika masyarakaat memandang komunitas motor ini memiliki banyak kegiatan yang negatif, mereka yakin bahwa JCRI dapat merubah cara pandangan masyarakaat bahwa komunitas motor ini tidak seperti yang mereka pikirkan selama ini. Selain optimis komunitas motor ini selalu bersabar dalam menghadapi suatu permasalahan, jika terjadi konflik atau permasalahan kepada masyarakaat,komunitas motor JCRI ini bersabar hingga harapan mereka terpenuhi.komunitas JCRI tidak akan berhenti untuk berusaha sampai komunitas motor ini dipandang positif terhadap masyarakaat, melalui pembuktian terhadap masyarakaat yang terkena bencana alam, mereka memberikan kebutuhan sandang dan pangan melalui kegiatan bakti sosial, selain itu JCRI membuktikan terhadap masyarakaat bahwa saat berada di jalan raya komunitas JCRI ini mematuhi semua tata tertib berlalu lintas, dari cara berpakaian, dan rambu-rambu lalu lintas.

Menjalin hubungan solidaritas yang kuat antar anggota dampak positif dari terbentuknya komunitas JCRI ini adalah menjalin hubungan pertemanan dan solidaritas diantara anggotanya. Saat mereka melakukan kumpul bareng yang bernama KOPDAR, KOPDAR (Kopi Darat) adalah kegiatan rutin yang dilakukan oleh setiap komunitas motor pada malam minggu, disanalah mereka melakukan sharing antar anggota komunitas pada saat mereka berkeliling kota Jogja, mereka melakukan kegiatan penambalan jalan. Tujuannya agar pengendara yang mengemudi di jalan tersebut terasa nyaman. Selain menambal jalan, komunitas ini terkadang memberikan makanan kepada orang yang membutuhkan pada malam hari. Selain itu komunitas motor ini melakukan kegiatan silahturahmi antar komunitas motor, tujuannya untuk mengenal komunitas satu dengan komunitas yang lainnya. Komunitas JCRI Dapat menyalurkan hobinya dan membagi pengalaman kepada anggota lain Kegiatan-kegiatan yang diadakan oleh komunitas JCRI dapat memberikan fasilitas kepada anggotanya untuk mengembangkan pengalaman dan hobi mereka dengan seorang rider lainnya dari berbagai daerah. 


\section{KESIMPULAN}

Berpikir positif merupakan salah satu hal yang penting yang dimiliki oleh setiap orang termasuk komunitas motor. Berpikir positif juga dapat membangun semangat komunitas motor dalam pandangan masyarakaat. Bepikir positif ini diharapkan dapat meningkatkan pandangan yang baik terhadap komunitas motor tersebut.

Secara garis besar dapat disimpulkan bahwa Jogja CBR Riders Independent (JCRI) adalah sebuah komunitas motor yang memiliki keinginan merubah pemikiran negatif masyarakaat menjadi pemikiran yang positif terhadap komunitas motor. JCRI membuktikan terhadap masyarakaat dengan adanya bakti sosial yang dilakukan oleh komunitas motor JCRI dengan menyumbangkan sandang dan pangan yang bermanfaat untuk masyarakat yang mendapat musibah banjir di Bantul. Pada saat observasi dalam komunitas motor JCRI mereka menjalin hubungan pertemanan dan solidaritas diantara anggotanya, saat mereka melakukan KOPDAR disanalah mereka melakukan sharing antar anggota komunitas, dan yang terakhir dapat menyalurkan hobinya dan membagi pengalaman kepada anggota lain kegiatan-kegiatan yang diadakan oleh komunitas JCRI.

Bukan hanya sekedar itu saja saat mereka melakukan konvoi dijalan raya,mereka tetap mentaati perarturan beralalu lintas seperti, menggunakan helm, sepatu, jaket, sarung tangan, dan atribut sehingga mereka dapat dikenal oleh masyarakaat, selain itu juga mereka saat mentaati perarturan rambu-rambu lalu lintas yang ada.

Dengan sikap yang baik dan membantu masyarakat, komunitas memiliki harapan agar masyarakat tidak lagi berpikir negatif kepada setiap komunitas motor, tidak semua komunitas motor itu buruk tetapi di dalamnya terdapat hal-hal yang positif yang sangat bermanfaat untuk kita pelajari. 


\section{DAFTAR PUSTAKA}

Elfiky, I. (2008). Terapi berpikir positif. Jakarta: Zaman.

Hermawan. K . (2008). Arti komunitas. Jakarta: Gramedia Pustaka Utama.

Hurlock, E. B. (2006). Psikologi perkembangan suatu pendekatan sepanjang rentang kehidupan. Jakarta: Penerbit Erlangga.

Sakina, E. (2008). Berpikir Benar, Berpikir Positif: Bandung: Alfa Beta.

Soerjono, S. (2006). Sosiologi suatu pengantar. Jakarta: Rajawali Pers.

Tentama, F. (2010). Berpikir positif dan penerimaan diri pada remaja penyandang cacat tubuh akibat kecelakaan. Humanitas VII(1), 66-75.

Tentama, F. (2012). Membangkitkan pikiran positif difabel. Republika, 76.

Tentama, F. (2014) Hubungan positive thinking dengan self-acceptance pada difabel (bawaan lahir) di SLB negeri 3 Yogyakarta. Jurnal psikologi integratif, 2(2), 1-7.

Peale, N.V. 1996. The power of positive thinking. F.X Budiyanto (terj.). Jakarta: Binarupa Aksara.

Ubaedy. (2007). Kedahsyatan Berpikir Positif. Depok : PT Visi Gagas Komunika.

Wellman, B., \& Gerard, D. (2003). 2012. Pengertian komunitas sosial. http://frontlinerinc.com/2012/02/pengaruhkomunitas-sosial-terhadap-keputusanpembelian-dan-sikapterhadap- merek-part-1/ 